\title{
Conservation Opportunities and Local Community Attitudes towards Wildlife in Harenna Forest, South East Ethiopia
}

Mekonen $\mathbf{S}^{1^{*}}$, Chinasho $\mathrm{A}^{2}$, Berhanu $\mathrm{K}^{3}$ and Tesfaye $\mathbf{S}^{4}$

${ }^{1}$ Department of Wildlife and Ecotourism Management, Wolkite University, Ethiopia

${ }^{2}$ Department of Environmental Science, Wolaita Sodo University, Ethiopia

${ }^{3}$ Department of Tourism Management, Debre Berehan University, Ethiopia

${ }^{4}$ Department of Tourism Management, Madda Walabu University, P. O. Box 247, Ethiopia

\begin{abstract}
The study was conducted in Harenna Forest between March and June, 2016, with the objectives of assessing the conservation opportunities and local community attitudes towards wildlife in the communities. Questionnaire, interviews and focus group discussions were used to collect data. A total of 340 respondents were included for household questioner by systematic random sampling method while 11 respondents were purposively selected and for an in-depth interview survey. The data revealed that in terms of the opportunities of wildlife conservation, respondents' responses mostly agreed for the existence of benefit sharing between locals and government $(50 \%)$, presence of conservation organizations $(89.7 \%)$, local communities are well aware and keen on wildlife $(68.9 \%)$, community participation to conserve wildlife $(78.5 \%)$, full sense of ownership towards the forest and wildlife $(74.2 \%)$, management programmes implementation $(78.6 \%)$, high priority of government bodies for conservation $(89.1 \%)$ and an education and awareness creation program $(74.1 \%)$. Out of the total respondents, $19(5.59 \%)$ opposed the existing wildlife conservation systems, while $317(93.23 \%)$ supported. Despite these existing wildlife conservation opportunities, wildlife continue to be threatened in and around the Harenna forest through overgrazing by livestock, firewood collection, settlement and agriculture expansions and wildfires. In addition, local community pays less attention to conservation of forest and wild animals. This study therefore, recommend that, enhancement awareness creation programme and involvement of local people in the participation of wildlife in Harenna Forest Conservation Area.
\end{abstract}

Keywords: Attitudes; Harenna Forest; Opportunities; Wildlife Conservation

\section{Introduction}

Wildlife resources constitute a vital link in the survival of the human species and have been a subject of much fascination, interest, and research all over the world. Today, when wildlife habitats are under severe pressure and a large number of species of wild fauna have become endangered, the effective conservation of wild animals is of great significance. Because every one of us depends on plants and animals for all vital components of our welfare, it is more than a matter of convenience that they continue to exist; it is a matter of life and death [1].

However, Ethiopian wildlife resources are under ongoing pressure due to direct causes (i.e. habitat conversion, unsustainable utilization, and invasive species, replacement of local varieties and breeds, climate change, pollution and direct causes (demographic change, poverty, and lack of awareness and coordination) [2-4]. Wildlife conservation opportunities like positively contribute to economic growth, wealth creation and increased employment are being lost in Ethiopia as increasing wildlife threats. So far, and because of issues of management, communities consider the presence of wildlife as a burden rather than an opportunity for gaining benefits [5].

Ethiopia has variable topography, ecosystems and habitats and diverse climatic conditions. As a result, Ethiopia is one of the top twenty-five richest countries in the world in terms of biodiversity [6]. Ethiopia hosts two of the biodiversity hotspots of the world, namely: the Eastern Afromontane and the Horn of Africa hotspots [4]. Country's unique topography and biological diversity have resulted in a high level of endemism. The biodiversity resource plays key roles in economic, ecological and social fabrics in Ethiopia [7].

Ethiopia's wildlife is one of the richest and most diversified in Africa with several of its protected areas and wetlands. Out of the total wildlife resources, more than 320 mammals (39 endemic), 918 birds (19 endemic), 240 reptiles (16 endemic), 71 amphibians (30 endemic) and 172 fishes (38 endemic) species are recorded in Ethiopia $[5,8]$. The country also has a wide variety of wildlife habitats ranging from alpine moor lands to lowland savannahs with extensive wetlands. Having evolved on relative ecological isolation from the rest of African mainland, the country contains approximately $40 \%$ of all land above $2,500 \mathrm{~m}$ in altitude.

Harena forest is one of the largest forests in Ethiopia, covering an area of over $4,000 \mathrm{~km}^{2}$ which is equivalent to about half of the Bale Mountains National park's total area (Figure 1) and along with the adjacent Stateand community-managed forest outside the park $[9,10]$. The forest is also one of the biggest hotspots rich in ecosystem and biodiversity and its known for a diversity of mammals, birds, amphibians, and a variety of plants and many other species and it's also the origin of the Harenna Wild Coffee.

However, Harenna forest wildlife resources and their habitats are under threat/vulnerable by many factors. In order to mitigate such threats, the present investigation has been conducted to document

*Corresponding author: Mekonen S, Department of Wildlife and Ecotourism Management, Wolkite University, Ethiopia, Tel: +251 11543 2311; E-mail: mekonen.sefi@gmail.com

Received October 30, 2017; Accepted December 08, 2017; Published Decembe 12, 2017

Citation: Mekonen S, Chinasho A, Berhanu K, Tesfaye S (2017) Conservation Opportunities and Local Community Attitudes towards Wildlife in Harenna Forest, South East Ethiopia. J Biodivers Endanger Species 5: 203. doi: 10.4172/2332-2543.1000203

Copyright: @ 2017 Mekonen S, et al. This is an open-access article distributed under the terms of the Creative Commons Attribution License, which permits unrestricted use, distribution, and reproduction in any medium, provided the original author and source are credited. 
Citation: Mekonen S, Chinasho A, Berhanu K, Tesfaye S (2017) Conservation Opportunities and Local Community Attitudes towards Wildlife in Harenna Forest, South East Ethiopia. J Biodivers Endanger Species 5: 203. doi: 10.4172/2332-2543.1000203

data on the conservation opportunities and local community attitudes towards existing wildlife and conservation practices in the study area.

\section{Research Methodology}

\section{Description of the study area}

Harenna Forest is a moist Afromontane Forest, located in South Eastern part of Oromia regional state. It is a state forest found in Bale Mountain National Park and it is situated on the southern slopes of the Bale Mountain, about $480 \mathrm{~km}$ from Addis Ababa, Ethiopia (Figure 1). Harenna Forest is located approximately between latitude $60^{\circ} 20^{\prime}$ and $60^{\circ} 50^{\prime} \mathrm{N}$ and longitudes $39^{\circ}$ and $40^{\circ} \mathrm{E}$. Along with the adjacent Stateand community-managed forest outside the park, it constitutes an area of over $4,000 \mathrm{~km}^{2}$. It is also the largest cloud forest in the country. It lies between an altitude of $3300 \mathrm{~m}$ to $1150 \mathrm{~m}$ asl [11].

\section{Vegetation and animals}

Mountain bamboo grows within the forest, particularly on steep slopes. The upper area of the Harenna forest is wet cloud forest with an extensive bamboo belt, while the lower parts are drier mountain forest. At about 2,200 $\mathrm{m}$ as the slopes become gentler, larger trees of up to $30 \mathrm{~m}$ tall appear, and the canopy closes [10]. In the lower areas of the forest, wild forest coffee (Arabica sp.) grows. Because the forest is so dense and clearings are few and far between, the elusive animals of the forest have little trouble staying hidden. Black-and-white colobus monkey, olive baboon, warthog and Menelik's bushbuck are common. With a little luck and perseverance, you might see a giant forest hog, a bush pig or an endemic Bale monkey [12]. Clearings are the best places to look for lion, leopard and African wild dog. Genet, civet, porcupine, and hyena are all active at night. Birds of the Harenna forest are equally elusive. Look for the Abyssinian hillbabbler, Abyssinian crimson-wing, Ayre'shawk eagle, silvery-cheekedhornbill, black-winged lovebird, Abyssinian oriole, yellow-fronted parrot, white-cheeked turaco and Narina trogon. A wide range of migrant birds can also be spotted, including Palearctic warblers [9].

\section{Methodology and data collection}

Both primary and secondary sources of data were used. Primary data were gathered via household survey, focus group discussion (FGD), in depth interview and observation to find out information related with factors which devastate wildlife resources as well as factors which enhance conservation practices within the forest. Secondary sources of data including, journal articles, websites, action plans, minutes, folders, brochures/leaflets and GMP of the parks, reports, bulletin and proceedings, Oromiya Forest Enterprises, Farm Africa, Agriculture and Rural Development Offices, Land and Natural Resource Conservation Offices, Culture and Tourism Offices, Frankfurt Zoological Society, Ethiopian Wolf Conservation Program and Ethiopian Wildlife Conservation Authority were reviewed to get an idea about the practice and challenges of wildlife conservation.

A household questionnaire survey was conducted. The questionnaire was first prepared in English and translated into Afaan Oromo language. The questionnaire contained both closed and opened ended sentences. While close ended items were used to help a researcher examine respondents' response about the conservation and challenges or opportunities for wildlife conservation, open ended questions were particularly to identifying the reasons why respondents hold some kind of view on related issues The survey questions included a category with closed style items requiring the respondents to rank their rate of agreement with a particular item such as 'yes' or 'no'; 'increasing', 'decreasing' and stable; and a 3-point Likert scale (where 1=disagree; $2=$ neutral; and $3=$ agree) depending on a particular question.

For household surveys, a total of 10 villages were selected purposively based on proximity to forest resources. According to HarennaBuluk, District Agriculture and Rural Development Office records,(2015), there are (in words) 8883 households in the (ten) 10 villages. The sample size was determined using Israel [13] sample size determination formula:

$$
\mathrm{nT}=\frac{\mathrm{N}}{1+\mathrm{N}\left(\mathrm{e}^{2}\right)},
$$

Where $\mathrm{n}$ is number of sampled households,

' $N$ ' is total target population,

$\boldsymbol{n}_{T}$ is total number of household, and

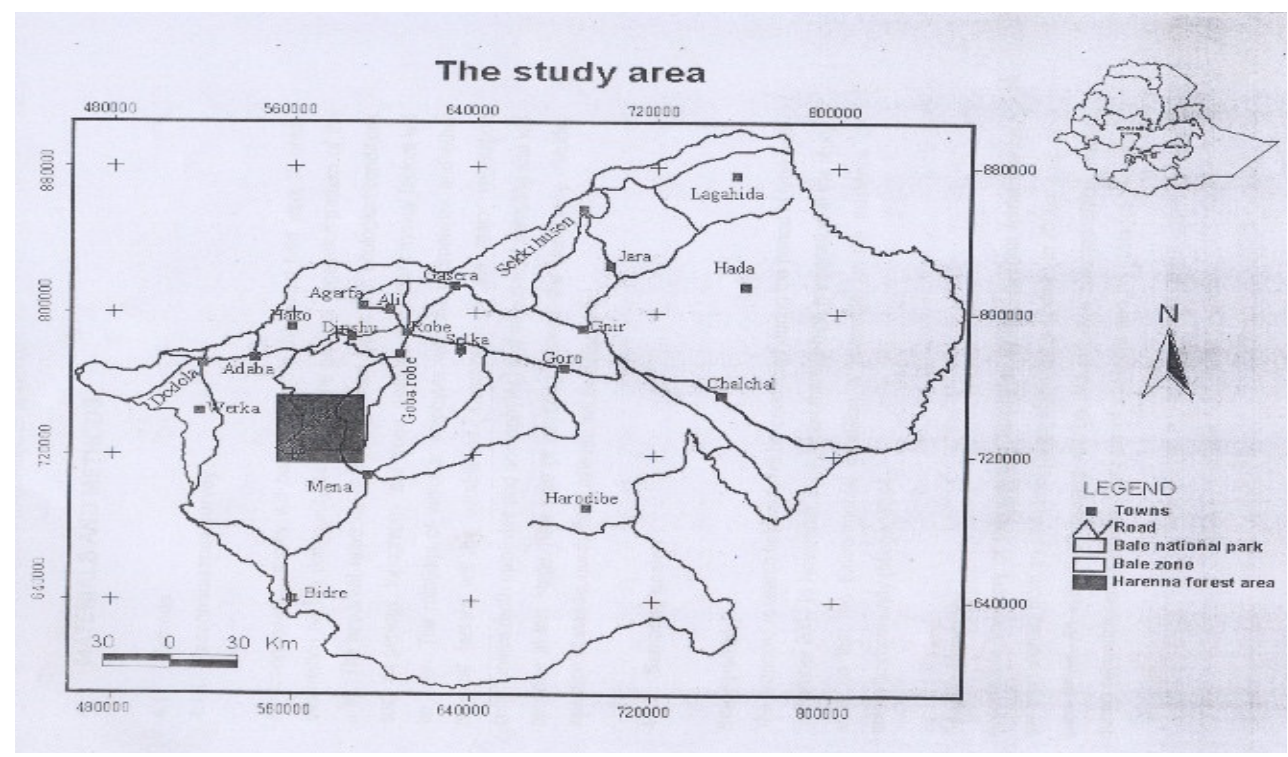

Figure 1: Map of Harenna forest [11] 
Citation: Mekonen S, Chinasho A, Berhanu K, Tesfaye S (2017) Conservation Opportunities and Local Community Attitudes towards Wildlife in Harenna Forest, South East Ethiopia. J Biodivers Endanger Species 5: 203. doi: 10.4172/2332-2543.1000203

$\boldsymbol{e}$ is level of precision.

Hence, according to the formula, sample size determined at $5 \%$ precision and $95 \%$ of confidence level was 388 households.

That is $\mathrm{n}_{\mathrm{T}}=8883 / 1+8883(0.05)^{2}=\underline{382}$.

In order to determine the sample size of each village, stratified sampling techniques were employed. According to Kothari [14], in stratified sampling technique, the sample size of different stratum is determined proportional to the size of population. Hence, the sample size of each village (nv) was:

$$
\mathrm{nv}=\frac{\text { Number of households }}{8883} \times 382
$$

In-depth interviews were carried out using structured and semistructured questions. In doing so the participants for the in depth interview were selected purposively based on the responsibilities they have, experience, and relevance to issues understudy.

The questionnaires were administered to the following in Harenna Bulluk District: Agriculture and Rural development Office (1 animal science expert, 1 plant science expert), District land and natural Resource Conservation Office (2 Natural resource management experts), Farm Africa (1 manager, 1 wildlife and community expert), Oromiya forest enterprise (1 conservation expert), District " $\mathrm{S}$ " Court (2 judges), District Police Office (2).

Two Focus Group Discussions (FGD) were conducted with experts from farm Africa and tourism, Natural resource, plant science, animal science, wildlife and Oromiya Forest Enterprise). The second FGD was with local communities, (religious leaders, forest dwellers association and village administrators. The issues discussed included the current challenges for wildlife conservation, the opportunities for conservation and possible solutions for challenges of conservation.

\section{Data analysis}

Statistical package software SPSS version 16.0 was used to analyze the questionnaire data. While Quantitative data was treated using descriptive statistical presentations such as percentages, frequencies and mean were used to analyze the FGD. The finding from quantitative data was presented or reported through tables, and bars. In addition, the findings of questionnaires were integrated and compared with that of in-depth interviews, field observation, Focus group discussion and document analysis.

\section{Results}

\section{Demographics characteristics of respondents}

Out of 382 household questionnaire surveys, a total of 340 respondents answered questions effectively. Of these, $63.5 \%$ were males and $36.5 \%$ were females (Table 1 ).

\section{Opportunities for wildlife conservation}

Regarding the opportunities for wildlife conservation (Table 2), the percentage values of respondents' responses mostly responses agree for the existence of benefit sharing between locals and government (50\%), presence of conservation organizations (89.7\%), local communities are well aware and keen on wildlife (68.9\%), high level of community participation to conserve wildlife (78.5\%), local community has full sense of ownership towards the forest and wildlife (74.2\%), management programmes are being implemented $(78.6 \%)$, high priority of Government bodies for conservation (89.1\%) and an education and awareness creation program (74.1\%). The remaining percentage of respondents were generally in disagreement and partly neutral with regards to opportunities derived from wildlife conservation. For instance, $73.5 \%$ and $43.6 \%$ of respondents disagreed on tourist flow in the area and enough trained staffs to manage activities of the forest respectively as opportunities for wildlife conservation in Harennaforest.

According to 11 respondents who were included in the depth interview, there were 7 main wildlife conservation opportunities around Harenna forest (Table 3). Regarding to these opportunities, the respondents stated $36.36 \%$ agree, $20.45 \%$ disagree, $15.91 \%$ strongly agree, $14.77 \%$ disagree and $12.5 \%$ neutral.

The FGD of expert discussions showed that all the adjacent communities of Harenna forest mainly benefited from forest resources.

\begin{tabular}{|l|c|c|c|}
\hline $\begin{array}{l}\text { Background of the } \\
\text { respondents }\end{array}$ & $\begin{array}{c}\text { No. of } \\
\text { respondents }\end{array}$ & Percentage \\
\hline \multirow{3}{*}{ Sex } & Male & 216 & 63.5 \\
\hline \multirow{3}{*}{ Age } & Female & 124 & 36.5 \\
\hline \multirow{3}{*}{ Educational Status } & Adult (18-35) & 138 & 40.6 \\
\cline { 2 - 4 } & Middle (36-45) & 158 & 46.5 \\
\cline { 2 - 4 } & Elder (>46) & 44 & 12.9 \\
\hline \multirow{3}{*}{ Household economy } & Uneducated & 178 & 52.4 \\
\cline { 2 - 4 } & Elementary & 95 & 27.9 \\
\cline { 2 - 4 } & 2ndry school & 22 & 6.5 \\
\cline { 2 - 4 } & College & 23 & 6.8 \\
\cline { 2 - 4 } & University & 22 & 6.5 \\
\cline { 2 - 4 } & Agriculture & 20 & 5.88 \\
\cline { 2 - 4 } & Trade & 17 & 5.00 \\
\cline { 2 - 4 } & Movernmental work & 38 & 71.18 \\
\hline
\end{tabular}

Table 1: Background of the respondents involved in questionnaire survey.

\section{Opportunities for wildlife conservation}

1. Benefit sharing $b / n$ locals and government

2. Presence of conservation organizations

3. Local communities are well aware and keen on wildlife

4. High level of community participation to conserve wildife

5. Local community has full sense of ownership towards the forest

6. Management programs are being implemented

7. Tourist flow in the area

8. High priority of Government bodies for conservation

9. Enough trained staffs to manage over all activities of the forest

10. An education and awareness creation program

\begin{tabular}{|c|c|c|}
\hline \multicolumn{3}{|c|}{ Scale (\%) } \\
\hline Agree & Neutral & Disagree \\
\hline 50.0 & 20.6 & 29.4 \\
\hline 89.7 & 5.0 & 5.3 \\
\hline 68.9 & 10.9 & 20.3 \\
\hline 78.5 & 11.2 & 10.3 \\
\hline 74.2 & 12.4 & 13.4 \\
\hline 78.6 & 10.0 & 11.4 \\
\hline 16.5 & 10.0 & 73.5 \\
\hline 89.1 & 7.6 & 3.3 \\
\hline 35.6 & 20.9 & 43.3 \\
\hline 74.2 & 12.9 & 12.9 \\
\hline
\end{tabular}

Table 2: Responses of respondents regarding the opportunities for wildlife conservation. 
Citation: Mekonen S, Chinasho A, Berhanu K, Tesfaye S (2017) Conservation Opportunities and Local Community Attitudes towards Wildlife in Harenna Forest, South East Ethiopia. J Biodivers Endanger Species 5: 203. doi: 10.4172/2332-2543.1000203

Most participants agreed that the resources obtained from the forest area were grass, fuel wood collection, water towers, for grazing of livestock during opening and drought season, wild coffee and honey.

With regards to wildlife conservation opportunities, most of the local communities discussants stated that "we the nearby communities can't survive without Harenna forest because it is as our cloth and bread (libsachininagursachin). Most experts from different sectors reported that the Harenna forest resources benefited the local community but their utilization of the resources was not in a regular manner resulting in the unsustainable utilization of the resources. There are community based organizations which are organized and supported by non-govenmental organization like Farm Africa and Oromia Forest and Wildlife Enterprise. These organizations have different names in different Villages of HarennaBuluk district. For instance, Badise in Shawee, Badhatu in Kumbi and Wolmale in Sodokebele of the district.

Attitude and perception of local communities on wildlife

\section{conservation}

Out of the 340 respondents, 19 (5.59\%) opposed the existing wildlife conservation systems, while majority, 317 (93.23\%) were in agreement (Table 4). However, there was a significant difference in attitude towards the conservation of wildlife among village (Kebele) residents $\left(\mathrm{x}^{2}=38.62\right.$, $\mathrm{DF}=18, \mathrm{P}=0.003$ ), though four Villages, namely, Heeroo, Soorbiraa, Suduweelmel and Sodu Lalaftoo showed in total $100 \%$ positive attitudes to wildlife conservation. There was no significant difference in the attitude towards wildlife conservation between different age classes $\left(\mathrm{x}^{2}=0.743, \mathrm{DF}=4, \mathrm{P}=0.946\right)$. Sex was also not important in determining the attitude towards conservation area $\left(\mathrm{x}^{2}=1.38, \mathrm{DF}=2, \mathrm{P}=0.501\right)$. Relatively better-educated groups (elementary, secondary, college and university) ( $\left.\mathrm{x}^{2}=9.632, \mathrm{DF}=8, \mathrm{P}=0.005\right)$ had more positive attitude than non-educated groups (illiterate and read and write only group).

Most local community respondents also had positive attitude towards wildlife for its importance to attract tourists, hunting

\begin{tabular}{|c|c|c|c|c|c|c|c|}
\hline \multirow[b]{2}{*}{ No } & \multirow[b]{2}{*}{ Items related to opportunities of wildlife conservations } & \multicolumn{5}{|c|}{ Scale } & \multirow[b]{2}{*}{$\begin{array}{l}X^{2} \text { values significance with } \\
\text { different offices respondents }\end{array}$} \\
\hline & & 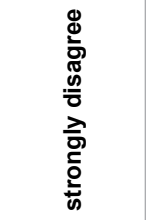 & 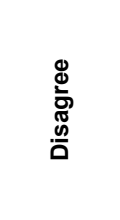 & $\begin{array}{l}\bar{\pi} \\
\overline{2} \\
\frac{0}{3} \\
z\end{array}$ & ষ & 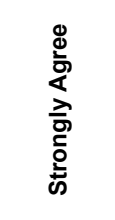 & \\
\hline & Abundance and variety of indigenous fauna and floras & 1 & 1 & 2 & 2 & 5 & $X^{2}=17.600, D F=20, P=0.614$ \\
\hline & Availability of natural water & & 1 & & 7 & 3 & $X^{2}=10.476, D F=10, P=0.400$ \\
\hline & Awareness on nature conservation issues & 1 & & 1 & 6 & 3 & $X^{2}=17.417, D F=15, P=0.295$ \\
\hline & The number of visitors to the forest is increasing & 2 & 1 & 4 & 3 & 1 & $X^{2}=19.250, D F=20, P=0.506$ \\
\hline & Well promotion of forest & 3 & 3 & & 3 & 2 & $X^{2}=13.750, D F=15, P=0.545$ \\
\hline & Activities to maintain biodiversity & 2 & 2 & & 7 & & $X^{2}=11.393, D F=10, P=0.328$ \\
\hline & $\begin{array}{l}\text { Adequate financial allocation for forest and wildlife } \\
\text { management }\end{array}$ & 3 & 5 & 1 & 2 & & $X^{2}=17.233, D F=15, P=0.305$ \\
\hline & Total Frequency & $13(14.77 \%)$ & $\begin{array}{c}18 \\
(20.45 \%)\end{array}$ & $\begin{array}{c}11 \\
(12.5 \%)\end{array}$ & $\begin{array}{c}32 \\
(36.3 \%)\end{array}$ & $\begin{array}{c}14 \\
(15.91 \%)\end{array}$ & \\
\hline
\end{tabular}

Table 3: Opportunities of wildlife conservations on the view of interview.

\begin{tabular}{|c|c|c|c|c|c|c|c|c|c|c|c|c|}
\hline \multirow[t]{2}{*}{ Attitude } & \multicolumn{10}{|c|}{ Kebele (\%) } & \multirow[b]{2}{*}{ Total } & \multirow[b]{2}{*}{ Community perception } \\
\hline & 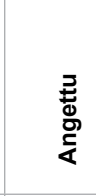 & 홀 & 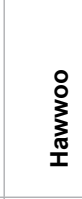 & 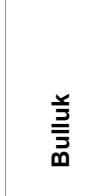 & 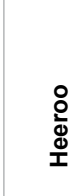 & $\begin{array}{l}\frac{\pi}{\pi} \\
\frac{\pi}{2} \\
\frac{2}{2} \\
0 \\
0\end{array}$ & 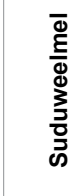 & 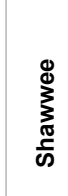 & $\begin{array}{l}\stackrel{8}{0} \\
\frac{+}{\pi} \\
\frac{\pi}{\pi} \\
\frac{1}{5} \\
\frac{7}{0} \\
\infty\end{array}$ & 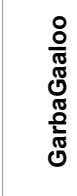 & & \\
\hline Positive & 82.8 & 96.3 & 97.6 & 77.3 & 100 & 100 & 100 & 92 & 100 & 96.6 & $317(93.23 \%)$ & $\begin{array}{ll}\diamond & \text { For tourism } \\
\diamond & \text { Cultural value } \\
\diamond & \text { Job opportunity } \\
\diamond & \text { Aesthetic value }\end{array}$ \\
\hline Negative & 10.3 & 3.7 & 2.4 & 20.4 & 0 & 0 & 0 & 6 & 0 & 3.4 & $19(5.59 \%)$ & $\begin{array}{l}\text { - } \quad \text { No benefit from the forest } \\
\text { - } \quad \text { Problem with wildlife } \\
\text { in the forest } \\
\text { - } \quad \text { Lack of access to arable } \\
\text { land } \\
\text { Limit our interest of } \\
\text { settlement }\end{array}$ \\
\hline Neutral & 6.9 & 0 & 0 & 2.3 & 0 & 0 & 0 & 2 & 0 & 0 & $4(1.18 \%)$ & \\
\hline
\end{tabular}


Citation: Mekonen S, Chinasho A, Berhanu K, Tesfaye S (2017) Conservation Opportunities and Local Community Attitudes towards Wildlife in Harenna Forest, South East Ethiopia. J Biodivers Endanger Species 5: 203. doi: 10.4172/2332-2543.1000203

Page 5 of 6

opportunities, enjoyment derived from viewing wildlife and its value for future generation. All expert and almost all local community discussants agreed and reported that conserving wildlife is important.

\section{Discussion}

Regarding the opportunities for wildlife conservation, most respondents were of the view that it; provided a platform for benefit sharing of resources between locals and government, encouraged the presence of conservation organizations, enabled local communities to be well aware and keen on wildlife issues, facilitated a high level of community participation to conserve wildlife, enabled local communities to have a full sense of ownership towards the forest and wildlife, expedited actions of government bodies for engaging in conservation, education and awareness creation programmes. The presence of these opportunities might be important to conserve wildlife resources in Harenna forest in line with the findings of Amare $[5,15]$.

The presence of these opportunities might be important to conserve wildlife resources in Harenna Forest and in line with the findings of Amare [5,15]. The presences of biodiversity-related conservation organizations have different roles for conservation and sustainable utilizations [16]. Non-governmental organizations like Farm Africa, SOS Ethiopia, Oromia Forest and Wildlife Enterprise and government institutions like Harenna Buluk District Natural Resources and Environmental Conservation offices have their roles for conservation of wildlife and forest which is used as an opportunity of wildlife conservation for Harenna Forest.

A vitally important consideration for wildlife conservation is community support for wildlife conservation [17-19]. In line with this, study findings indicated that most (93.23\%) of the respondents had a positive attitude towards wildlife and wildlife conservation programmes, while only $5.59 \%$ had negative attitude. The general positive perceptions of respondents about wildlife in terms of recreational, tourism, cultural and educational values of wildlife played a major role in influencing the overall positive community attitude. Based on such positive values and attitudes portrayed from the local community, it is not surprising that most respondents wanted to get involved in the management and conservation of wildlife. It should however be acknowledged that a few of the respondents had no interest in wildlife conservation activity mainly due to access restriction problems, as well as frequent crop damage problems, conflict with grass collectors and livestock competition tendency of wildlife were the main reasons of the local community's dislike of the presence of wild animals.

This seemingly small negative attitude might grow into a big wildlife conservation challenge in Harenna forest if steps are not taken to address it. For instance, the area continues to face growing demands of firewood, fodder and livestock grazing. Illegal and unsustainable harvest of non-timber forest products has become a threat to conservation of wildlife. Conflicts over natural resources between the communities living adjacent to forest have increased because of changes in land use and accompanying new ideas about wildlife resource management and utilization. These events also in line with other studies which have been done on other parts of Ethiopia $[5,20]$ have a potential negative impact on local wildlife resources.

\section{Conclusion and Recommendation}

The existence of benefit sharing between local people and government, presence of conservation organizations and management programmes, awareness creation to local communities on the benefits of wildlife, high level of community participation to conserve wildlife, local community participation for ownership towards the forest and wildlife, high priority of government bodies for conservation and an education and awareness creation program were the major opportunities to wildlife conservation.

In general, according to this finding the challenges to wildlife conservation were greater and are higher than that of opportunities. This requires measures to tackle these challenges by establishing a welltailored conservation programs to encapsulate all these challenges in order to explore the opportunities.

For sustainable utilization of wildlife, coexistence of wildlife and local people, and support wildlife conservation opportunities, the following recommendations and suggestions were made based on the findings:

- Increased awareness to different sectors and local communities should continue and be strengthened.

- Community-based conservation approaches must be strengthened;

- The implementation of local and national conservation regulations should be maintained;

- $\quad$ Furthermore, Madda Walabu University with governmental and nongovernmental conservation officials should establish conservation education center that helps to raise awareness to the community and to reduce wildlife conservation challenges in the Harena forest.

\section{Acknowledgements}

Authors would like to extend sincerely and heartfelt thanks to Madda Walabu University for providing fund to carry out this study. Much gratitude gives to the local people who live around the study area for their hospitality and willingness to share their information.

\section{References}

1. Hundal SS (2004) Wildlife Conservation Strategies and Management in India: An Overview. Species at Risk 2004 Pathways to Recovery Conference Organizing Committee, Victoria, B.C., Canada.

2. Daszak P, Cunningham AA, Hyatt AD (2000) Emerging infectious diseases of wildlife Threats to biodiversity and human health. Science287: 443-449.

3. Ho SS, Brossard D, Scheufele DA (2007) Public reactions to global health threats and infectious diseases. Publ Opin Quart 71: 671-692.

4. Institute of Biodiversity Conservation IBC (2014) Ethiopia's Fifth National Report to the Convention on Biological Diversity. Ethiopian Biodiversity Institute, Addis Ababa.

5. Amare A (2015b) Wildlife Resources of Ethiopia: Opportunities, Challenges and Future Directions: From Ecotourism Perspective: A Review Paper. Natural Resour 6: 405-422.

6. Gole TW (2003) Conservation and Use of Coffee Genetic Resources in Ethiopia: Challenges and Opportunities in the Context of Current Global Situations. Globalization and Equity: The 4th Annual Global Development Network Conference, Cairo, Egypt.

7. Abunie $L(2000)$ The Challenge of Conserving Ethiopian Wildlife: Overview. Walia 31: 56-61.

8. Vreugdenhil D, Vreugdenhil AM, Tilahun T, Shimelis A, Tefera Z (2012) Gap Analysis of the Protected Areas System of Ethiopia, with Technical Contributions. Nagelkerke L, Gedeon K, Spawls S, Yalden D, Berhanu L, Siege L (editors). Ethiopian Wildlife Conservation Authority (EWCA), Addis Ababa: Ethiopia.

9. EWCA (2013) A traveler's guide to Bale Mountains National Park.

10. GMP (General Management plan, 2007). Bale Mountains National Park 
Citation: Mekonen S, Chinasho A, Berhanu K, Tesfaye S (2017) Conservation Opportunities and Local Community Attitudes towards Wildlife in Harenna Forest, South East Ethiopia. J Biodivers Endanger Species 5: 203. doi: 10.4172/2332-2543.1000203

Page 6 of 6

General Management Plan compiled and Edited by Frankfurt Zoological Society and Institute of Biodiversity Conservation.

11. Tesfa Alemayehu(2006) Diversity and Ecology of Vascular Epiphytes in Harenna afromontaneforest, Bale, Ethiopia.

12. Williams S (2002) Bale Mountains a Guide Book. United Press, Addis Ababa, Ethiopia.

13. Israel GD (1992) Determining Sample Size; Fact Sheet PEOD-6: University of Florida, USA.

14. Kothari C (2004) Research Methodology: methods and techniques, second revised edition, New Age International $(P)$ Ltd. publishers, New Delhi, India.

15. Amare A (2015) Conservation Challenges of Gibe Sheleko National Park, Southwestern Ethiopia.Nat Resour 6: 286-289.

16. Adetoro AO, Opebiyi EO, Oyeleye DO (2012) Wildlife Conservation Education and awareness among Senior Secondary School Students in Old Oyo National Park. Scribes Guild Journals 1: 103-116.

17. Decker DJ, Evensen DTN, Siemer WF, Leong KM, Riley SJ, et al. (2010) Understanding risk perceptions to enhance communication about humanwildlife interactions and the impacts of zoonotic disease. J Inst Lab Anim Res 51: 255-261.

18. Decker DJ, Siemer WF, Wild MA, Castle KT, Wong D, et al. (2011) Communicating about zoonotic disease: Strategic considerations for wildlife professionals. Wildl Soc Bull 35: 112-119.

19. Decker DJ, Riley SJ, Siemer WF (2012) Human dimensions of wildlife management. Johns Hopkins University Press, Baltimore, Maryland, p: 304.

20. Magige FJ (2012) Human-Wildlife Interaction in Serengeti and Ngorongoro Districts of Tanzania: A Case Study on small Mammals. Tanzania J Science 38: 95-105. 